\title{
Dendritic cells loaded with tumor derived exosomes for cancer immunotherapy
}

\author{
Hongyu Liu ${ }^{1, *}$, Ling Chen ${ }^{1, *}$, Yaojun Peng ${ }^{2}$, Songyan $\mathrm{Yu}^{3}$, Jialin Liu ${ }^{1}$, Liangliang $\mathbf{W u}^{2}$, \\ Lijun Zhang ${ }^{2}$, Qiyan Wu${ }^{2}$, Xin Chang ${ }^{4}$, Xinguang $\mathbf{Y u}^{1}$ and Tianyi Liu ${ }^{2}$ \\ ${ }^{1}$ Department of Neurosurgery, Chinese PLA General Hospital, Beijing 100853, China \\ ${ }^{2}$ Key Laboratory of Cancer Center, Chinese PLA General Hospital, Beijing 100853, China \\ ${ }^{3}$ Department of Endocrinology, Chinese PLA General Hospital, Beijing 100853, China \\ ${ }^{4}$ Department of Clinical Laboratory, Weihai Municipal Hospital, Weihai 264200, Shandong, China \\ * Co-first author
}

Correspondence to: Tianyi Liu, email: tianyiliu08@hotmail.com Xinguang Yu, email: xinguang_yu@263.net

Keywords: tumor derived exosomes, dendritic cells, immunotherapy

Received: October 21, $2016 \quad$ Accepted: April 29, $2017 \quad$ Published: September 11, 2017

Copyright: Liu et al. This is an open-access article distributed under the terms of the Creative Commons Attribution License 3.0 (CC BY 3.0), which permits unrestricted use, distribution, and reproduction in any medium, provided the original author and source are credited.

\begin{abstract}
Exosomes are vesicles that can be secreted by many types of cell and released into the extracellular space. Studies have found that tumor derived exosomes (TEXs) can promote tumor growth and metastasis, as well as inhibit immune response through transferring their genetic information to the recipient cells. Given their functions in tumor progression, TEXs are considered as promising biomarkers for early detection of human malignancy. Dendritic cells (DCs), a type of antigen presenting cells, can induce tumor-specific $\mathrm{T}$ cell immune responses in carcinogenesis. Growing evidences have demonstrated that the matured DCs induced by TEXs exhibit enhanced anti-tumor effects that may be applied for cancer immunotherapy. Thus in this review, according to the previous studies, we summarized the effects of DCs loaded with TEXs in cancer immunotherapy.
\end{abstract}

\section{INTRODUCTION}

A small vesicle was firstly observed in sheep reticulocytes in 1983 [1]. Later Rose M. Johnstone defined it as exosomes [2]. Exosomes are 30-100 nm vesicles, which are secreted by almost all types of cell including tumor cells $[3,4]$. They are composed of proteins and nucleic acids that are associated with donor cells [5]. Exosomes also have specific membrane markers such as tetraspanins (e.g. CD9, CD63, CD81), heat-shock protein (Hsp70), major histocompatibility complex molecules (MHC I and II) and costimulatory molecules [6]. In 1996, Raposo et al. firstly reported that B-cell-derived exosomes induced antigen specific MHC class II restricted T-cell responses [7], and then Zitvogel et al. demonstrated that dendritic cells (DCs) pulsed with tumor-derived peptides elicited potent antitumor T-cell response in tumor-bearing mice in 1998 [8]. These results have indicated that exosomes have potential capacities for cancer immunotherapy. In 2001, Wolfers et al. found that tumor-derived exosomes could be used as a source of shared tumor rejection antigens for CTL cross-priming [8]. Based on the findings, tumorous immunotherapies researches were carried out in various malignancies, such as melanoma, glioma, hepatocellular carcinoma and renal cell carcinoma [9-14]. In this review, we will summarize the function and application values of DCs loaded with tumor derived exosomes in cancer immunotherapy, as well as the related mechanisms.

\section{Exosomes in cancers}

Exosomes are formed through endocytosis in cell membrane, and then resulting in formation of multivesicular bodies (MVBs) that can fuse with plasma membrane and be released to the extracellular space or 
body fluids via exocytosis (Figure 1). Exosomes can carry the contents of their host cells, including miRNAs, proteins, lipids, even DNAs. Therefore, exosomes maintain the part function of their host cells. Released from malignant cells, tumor derived exosomes (TEXs) can promote tumor growth through inhibiting differentiation of bone marrow cells [15-17], changing physiology of macrophages $[11,18,19]$, reducing NK cell cytotoxicity [20-22], and regulating the role of T cells [23-29]. TEXs also plays an important role in tumor metastasis through transporting their contents to recipient cells thus affecting intracellular signal pathway [30-35] (Figure 2). Compared with exosomes released from normal cells, the quantity of TEXs is significantly more because the malignant cells secrete about 10 times more exosomes than the normal cells (Table 1). Abundant of TEXs in tumor microenvironment may enhance tumor immune invasion via inhibiting the function of effector T cells and NK cells. TEXs may also play inhibitory roles in differentiation of DCs. TEXs can help the tumor cells escape from host immunosurveillance, thus facilitating tumor growth and metastasis [17, 20-22].

In the early time, researchers focused on their potential as diagnostic markers because TEXs could reflect the genotypes and phenotypes of their parent cells. Following studies confirmed that exosomes could be secreted to serum, urine, cerebrospinal fluid, and all of those indicated that it might be a novel diagnostic maker for cancer [35-39]. It had been confirmed that the miRNA level in TEXs in body fluid showed strong correlation with tumor progression compared to body fluids levels. The related investigations have been reported in glioma, ovarian cancer, lung cancer, hepatocellular carcinoma, gastric cancer, etc [40-44]. Long non-coding RNAs (LncRNAs) also have potential roles to act as new diagnostic and prognostic biomarkers. Recently, researchers have found that lncRNAs expression, which is low in cells, is increased in exosomes derived from glioblastoma, bladder cancer, laryngeal squamous cell carcinoma, colorectal cancer, gastric cancer, liver cancer, etc [38, 45-49]. In a word, detection of the genetic information in exosomes may be a promising way for early diagnosis and surveillance of malignancies.

In recent years, DCs derived exosomes (DEXs) have attracted more attentions due to its immunoregulatory capacity and immunotherapeutic effects in management of cancer. DEX has the ability to present Ags directly and indirectly to T cells, so that they can not only induce

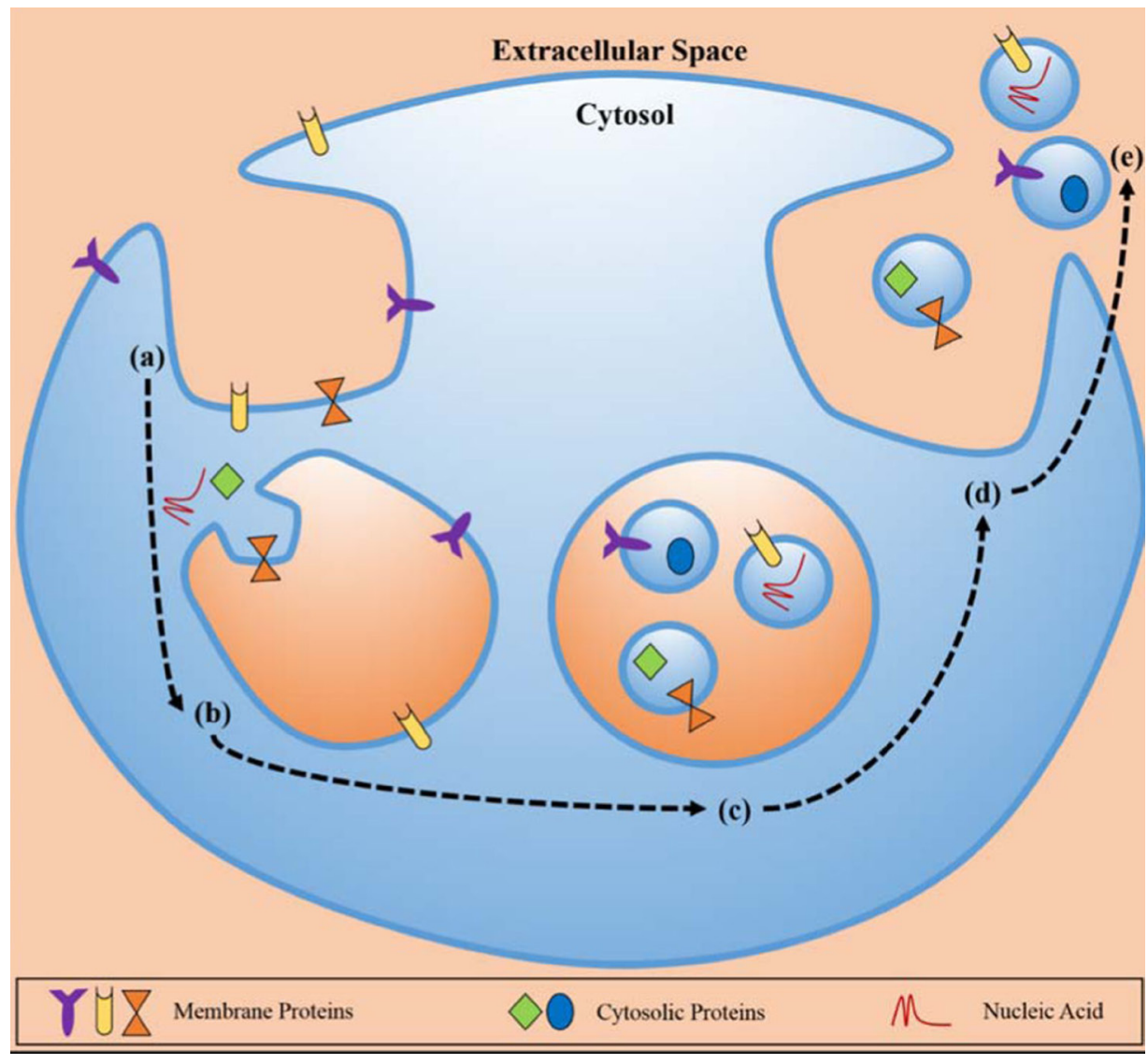

Figure 1: The biosynthetic pathway of exosomes. Exosomes was composed with proteins, cytosolic proteins, and necleic acid. Exosomes formation occurred at the membrane via enodocytosis, and related to the cellular environment through exocytosis (The figure from Munson et al. [73]). 
T cells dependent antitumor responses but also overcome some technical limitations of immunotherapy based on DCs. The therapeutic potential of DEX mainly depends on its composition. DEX contains abundant MHC Class I and II molecules, costimulatory molecules (CD80 and CD86), the Ig family member ICAM-1, milk fat globule EGF factor 8 (MFG-E8), tetraspanins (CD63, CD81, CD9) and the heat shock protein hsc73 [50-55]. DEX stimulates tumor-specific CTL responses by transferring $\mathrm{MHC}$ peptide complexes to T cells from DCs, which could be facilitated by costimulatory molecule and tetraspanin. ICAM-1, MFG-E8 and hsc73 also can promote immune reaction via inducing $\mathrm{T}$ cell-dependent antitumor response $[51,55]$. NK cell-dependent antitumor immune response can be activated by IL-15R, TNF, NKp30 ligand BAT3 and NKG2D expressed on the surface of DEX [56-58]. On the basis of those studies, DEX vaccine researches have been carried out for a variety of tumor cells [6, 59-62]. Moreover, phase I clinical trials in melanoma and advanced non-small cell lung cancer showed meaningful results $[63,64]$. Application of DEX vaccine may provide a promising approach for cancer prevention and treatments.

\section{TEXs contain tumor-associated antigen and can uptake by DCs}

Exosomes, derived from melanoma, glioma, renal cell carcinoma and other tumor cells, have been proved to contain parental antigens [7-13]. Wolfers et al. reported that tumor cells could secret exosomes, which strongly expressed MHCI, LAMP1, HSP70 and tumor antigens for the first time [7]. Andre et al found that antigens of exosomes could be taken up and cross-presented by MHC-I molecules in HLA-A2+ monocyte-derived DCs [65]. DCs not only express OVA and pMHC-I molecules, but also express both of them after being co-cultured with $\mathrm{EXO}_{\mathrm{EG} 7}$. This was correspond to the previous study that DCs became positive for CFSE or CD45.1 after being incubated with $\mathrm{EXO}_{\mathrm{CFSE}}$ or $\mathrm{EXO}_{6.1}$, and the expression of $\mathrm{H}-2 \mathrm{~Kb}$, pMHC.I, Ia ${ }^{\mathrm{b}}, \mathrm{CD} 40, \mathrm{CD} 54$ and $\mathrm{CD} 80$ in DCs was enhanced after incubation with $\mathrm{EXO}_{\mathrm{OVA}}$ $[66,67]$. While blocking the anti-LFA-1 and anti-DEC205 antibodies or treatment with cytochalasin D could reduce the uptake of exosomes in DCs, suggesting that LFA-1/ CD54 and C-type lectin/mannose-rich C-type lectin receptor interactions might be critical for the mechanism of exosomes uptake by DCs [67]. MHC-I (an important factor responsible for capturing antigenic peptide), ICAM-1 (an adhesive molecule which is potentially involved in cell targeting), HSP70 (a crucial chaperones for binding with DCs), and MAGE-1 protein (a glioma specific tumor antigen), were enriched in exosomes from malignant glioma than lysates [8]. Hepa1-6 TEXs express two wellcharacterized HCC antigens-alpha-fetoprotein (AFP) and glypican 3 (GPC3), and can be taken up by DCs, thereby promoting DC maturation through enhancing the expression levels of CD11c, MHC, co-stimulatory factors (CD80, CD86), and intercellular adhesion molecule (ICAM) [12]. WEHI3B-TEX, characterized by upregulated expression of the crucial receptors CD90, CD44, MFGE8, HSP70 and the tetraspanins CD9 and CD63, can be efficiently taken up by DCs, thus inducing

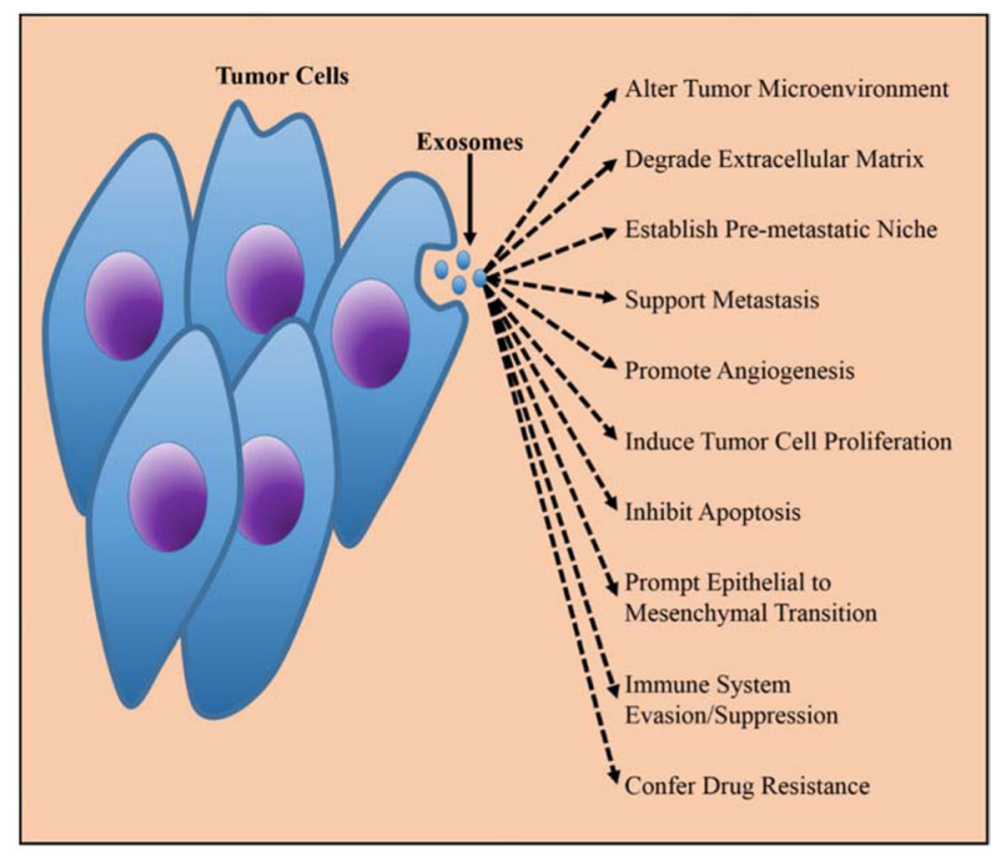

Figure 2: The biological function of TEXs in tumorigenesis. Released by the tumor cells, TEXs played important promoting roles in malignant progression of tumors via improving tumor environment, supporting metastasis, immunesuppressive, etc. The figure was from Munson et al. [73]. 


\begin{tabular}{|c|c|c|}
\hline & TEXs & Normal cell derived exosomes \\
\hline Origin & Tumor cells & Normal cells \\
\hline Biological components & $\begin{array}{l}\text { mRNAs, miRNAs, lnRNAs, } \\
\text { proteins, antigens, DNA, etc }\end{array}$ & mRNAs, miRNAs, lnRNAs, proteins, antigens, DNA, etc \\
\hline Quantity & $\begin{array}{l}\text { About } 10 \text { times more than the normal } \\
\text { cell derived exosomes }\end{array}$ & less than the numbers of the TEXs \\
\hline Characteristic protein & Cancer-specific antigen & $\begin{array}{c}\text { the proteins or protein family representing their endosomal } \\
\text { origin: for example exosomes from DCs carried abundant } \\
\text { of MHC class II and CD } 86\end{array}$ \\
\hline Function & $\begin{array}{l}\text { immune inhibition; promoting } \\
\text { angiogenesis, growth, invasion, } \\
\text { metastasis; drug resistance }\end{array}$ & $\begin{array}{l}\text { intercellular communication; anti-tumor action; immune- } \\
\text { stimulatory effects; }\end{array}$ \\
\hline Application & $\begin{array}{l}\text { tumor biomarkers and targeted } \\
\text { therapy }\end{array}$ & targeted delivery; cancer treatment \\
\hline
\end{tabular}

DCs maturation without impairment. TEXs carrying tumor specific antigen can activate maturation of DCs, enhancing anti-tumor immune response.

\section{DCs loaded with TEXs elicit CD8+ T cell dependent antitumor immunities}

In previous studies, it has been proved that TEXs uptake by DCs could induce antigen-specific CTL response. Tumor cells express antigens which can be recognized by CTLs. DCs take up the TEXs containing donor antigens, thereby inducing specific CTL response in vitro or in vivo. Andre et al. found the DCs loaded with ascitis exosomes from melanoma could increase the number of peripheral blood CD8 positive T cells and stimulate lymphocytes to lyse autologous tumour cells or release interferon-gamma. However, addition of antibodies to MHC class I molecules could inhibit the immune reaction [65]. Ning $\mathrm{Bu}$ et al. observed that TEXs uptake by DCs could activate the $\mathrm{T}$ lymphocytes to become glioma-specialized CTL, and they demonstrated that CD8 molecules antibodies could inhibit the CTL mediated cytotoxicity to tumor target cell, however antibodies to CD4 could not [8]. In immunotherapy of hepatocellular carcinoma, the number of $\mathrm{CD} 8+\mathrm{T}$ lymphocytes was increased significantly in serum and tumor tissues of mice treated with TEX-pulsed DCs [12]. Ye Yao et al. found that $\mathrm{EXO}_{\mathrm{EG} 7}$-targeted dendritic cells stronger stimulated CD8+ T-cell to differentiate into CTL effectors in vivo [66]. All the researches revealed that DCs loaded with TEXs could increase the numbers of CD8+ T cells, thus enhancing antitumor immunities.

\section{TEXs show stronger antitumor immunities than tumor derived lysate}

In recent years, more and more researches are devoted to explore DC vaccines for cancer prevention and treatments. The tumor lysates represent one of the most frequently used tumor antigens source for DC vaccines. They gain some achievements and also exhibit limited response rate [68]. The relevant studies demonstrated that the effect of TEXs was obviously better than tumor lysates. In Niken M. Mahaweni's study, the median survival for exosome-loaded DC group was longer than tumor lysate-loaded DC group (29.5 with 18.5 days), although mesothelioma-derived exosomes contained less proteins than necrotic tumor lysates [10]. Ning Bu et al. found that the cytotoxicity of exosomes DC-stimulated T cells against glioma cells was significantly greater than the levels in tumor lysate DC-stimulated T cells at all E:T ratios [8]. Hepa1-6 TEXs show superiority to cell lysates in eliciting DC-mediated antitumor immunity in vitro, despite of the capability of inhibiting tumor growth and $\mathrm{T}$ lymphocytes numbers in tumor tissues in vivo and cytolysis rates against hepa1-6 cells in vitro [12]. Some studies also showed that significantly stronger tumor suppression was achieved in tumor exosome-loaded DC -treated mice compared with tumor lysate-loaded $\mathrm{DC}$, because of the slower tumor growth, stronger CTL activation and DC taking up rate [7, 69]. DCs loaded with TEXs may be promising for tumor immune therapy without severe side effects and treatment resistance.

\section{Expansion}

In summary, exosomes have huge functions in tumor immunity. Exosomes can be utilized as a strongly efficient antigen compared with traditional tumor lysates because of its strong antigenicity, applicability and conveniences of storing and extracting. TEXs can be separated from blood by specific biomarker, which is suitable for all of the patients including the patients who couldn't tolerate surgical resection of the tumor. DCs capture and process antigens into peptides, and then present them to T cells receptors via major histocompatibility complex (MHC) class I or II thus activate signal 1 . The upregulating costimulatory molecules such as CD4+, CD8+ make 
DCs more mature and have more powerful capability in presenting antigens thus activate signal 2 to release a large number of cytokines, which must be completed by adjuvants. The therapeutic immunity of DC vaccines can be strengthened by pulse of some agents, such as Toll-like receptor (TLR) agonists, CD4+ ligand, CD7+, TNFRSF4 ligand, calcium ionophores, and GITR ligand. For example, recent studies demonstrated that the potent synthetic iNKTs agonist $\alpha$-galactosylceramide ( $\alpha$-GalCer) combined with DC vaccines could enhance capacity to drive conventional T-cell responses via upregulating immunostimulatory factors such as CD4+ upon encourage iNKT: DC interactions, then express highly effective in immunotherapy of glioma [70]. In addition, the DC vaccine efficacy is variable at present, and the most possible reason may be the immunosupressive response caused by tumor microenvironment. Recent studies show that immune checkpoint inhibitors such as PD-1 antibodies have abilities to relieve immunosuppression and improve the tumor microenvironment [71, 72]. However, application of TEXs loaded DC for cancer therapy has several potential challenges. First, it is well known that malignancy patients only produce dysfunctional DCs at early stages of disease. More attentions should be payed to isolated the eligible DCs with high quality for clinical use. Second, although in vitro demonstrated that TEXs could promote DCs maturation, there were a lots of TEXs in vivo which might suppress the function of DCs loaded with TEXs. Therefore, the application approaches for DCs use in cancer therapy required further improvements.

In conclusion, the combination of exosomes loaded by DC vaccine with adjuvants and immune checkpoint inhibitors maybe crucial for oncotherapy in the future. Further investigations should be devoted to improve the application strategies of DC vaccine loaded with TEXs for cancer treatments in clinic.

\section{CONFLICTS OF INTEREST}

None.

\section{REFERENCES}

1. Davis JQ, Dansereau D, Johnstone RM, Bennett V. Selective externalization of an ATP-binding protein structurally related to the clathrin-uncoating ATPase/heat shock protein in vesicles containing terminal transferrin receptors during reticulocyte maturation. The Journal of biological chemistry. 1986; 261:15368-15371.

2. Johnstone RM, Adam M, Hammond JR, Orr L, Turbide C. Vesicle formation during reticulocyte maturation. Association of plasma membrane activities with released vesicles (exosomes). The Journal of biological chemistry. 1987; 262:9412-9420.

3. Kesimer M, Scull M, Brighton B, DeMaria G, Burns K, O’Neal W, Pickles RJ, Sheehan JK. Characterization of exosome-like vesicles released from human tracheobronchial ciliated epithelium: a possible role in innate defense. FASEB journal. 2009; 23:1858-1868.

4. Yang C, Robbins PD. The roles of tumor-derived exosomes in cancer pathogenesis. Clinical \& developmental immunology. 2011; 2011:842849.

5. van Niel G, Porto-Carreiro I, Simoes S, Raposo G. Exosomes: a common pathway for a specialized function. Journal of biochemistry. 2006; 140:13-21.

6. Wolfers J, Lozier A, Raposo G, Regnault A, Thery C, Masurier C, Flament C, Pouzieux S, Faure F, Tursz T, Angevin E, Amigorena S, Zitvogel L. Tumor-derived exosomes are a source of shared tumor rejection antigens for CTL cross-priming. Nature medicine. 2001; 7:297-303.

7. Raposo G, Nijman HW, Stoorvogel W, Liejendekker R, Harding CV, Melief CJ, Geuze HJ. B lymphocytes secrete antigen-presenting vesicles. The Journal of experimental medicine. 1996; 183:1161-1172.

8. Zitvogel L, Regnault A, Lozier A, Wolfers J, Flament C, Tenza D, Ricciardi-Castagnoli P, Raposo G, Amigorena S. Eradication of established murine tumors using a novel cell-free vaccine: dendritic cell-derived exosomes. Nature medicine. 1998; 4:594-600.

9. Bu N, Wu H, Sun B, Zhang G, Zhan S, Zhang R, Zhou L. Exosome-loaded dendritic cells elicit tumor-specific CD8+ cytotoxic T cells in patients with glioma. Journal of neurooncology. 2011; 104:659-667.

10. Lee EY, Park KS, Yoon YJ, Lee J, Moon HG, Jang SC, Choi KH, Kim YK, Gho YS. Therapeutic effects of autologous tumor-derived nanovesicles on melanoma growth and metastasis. PloS one. 2012; 7:e33330.

11. Mahaweni NM, Kaijen-Lambers ME, Dekkers J, Aerts JG, Hegmans JP. Tumour-derived exosomes as antigen delivery carriers in dendritic cell-based immunotherapy for malignant mesothelioma. Journal of extracellular vesicles. 2013; 2.

12. Marton A, Vizler C, Kusz E, Temesfoi V, Szathmary Z, Nagy K, Szegletes Z, Varo G, Siklos L, Katona RL, Tubak V, Howard OM, Duda E, et al. Melanoma cell-derived exosomes alter macrophage and dendritic cell functions in vitro. Immunology letters. 2012; 148:34-38.

13. Rao Q, Zuo B, Lu Z, Gao X, You A, Wu C, Du Z, Yin H. Tumor-derived exosomes elicit tumor suppression in murine hepatocellular carcinoma models and humans in vitro. Hepatology. 2016; 64:456-472.

14. Zhang Y, Luo CL, He BC, Zhang JM, Cheng G, Wu XH. Exosomes derived from IL-12-anchored renal cancer cells increase induction of specific antitumor response in vitro: a novel vaccine for renal cell carcinoma. International journal of oncology. 2010; 36:133-140.

15. Yu S, Liu C, Su K, Wang J, Liu Y, Zhang L, Li C, Cong Y, Kimberly R, Grizzle WE, Falkson C, Zhang HG. Tumor exosomes inhibit differentiation of bone marrow dendritic cells. J Immunol. 2007; 178:6867-6875. 
16. Liu Y, Xiang X, Zhuang X, Zhang S, Liu C, Cheng Z, Michalek S, Grizzle W, Zhang HG. Contribution of MyD88 to the tumor exosome-mediated induction of myeloid derived suppressor cells. The American journal of pathology. 2010; 176:2490-2499.

17. Yang C, Kim SH, Bianco NR, Robbins PD. Tumor-derived exosomes confer antigen-specific immunosuppression in a murine delayed-type hypersensitivity model. PloS one. 2011; 6:e22517.

18. Chow A, Zhou W, Liu L, Fong MY, Champer J, Van Haute D, Chin AR, Ren X, Gugiu BG, Meng Z, Huang W, Ngo V, Kortylewski M, et al. Macrophage immunomodulation by breast cancer-derived exosomes requires Toll-like receptor 2-mediated activation of NFkappaB. Scientific reports. 2014; 4:5750.

19. Menck K, Klemm F, Gross JC, Pukrop T, Wenzel D, Binder C. Induction and transport of Wnt 5a during macrophageinduced malignant invasion is mediated by two types of extracellular vesicles. Oncotarget. 2013; 4:2057-2066. https:// doi.org/10.18632/oncotarget.1336.

20. Szczepanski MJ, Szajnik M, Welsh A, Whiteside TL, Boyiadzis M. Blast-derived microvesicles in sera from patients with acute myeloid leukemia suppress natural killer cell function via membrane-associated transforming growth factor-beta1. Haematologica. 2011; 96:1302-1309.

21. Liu C, Yu S, Zinn K, Wang J, Zhang L, Jia Y, Kappes JC, Barnes S, Kimberly RP, Grizzle WE, Zhang HG. Murine mammary carcinoma exosomes promote tumor growth by suppression of NK cell function. J Immunol. 2006; 176:1375-1385.

22. Clayton A, Mitchell JP, Court J, Linnane S, Mason MD, Tabi Z. Human tumor-derived exosomes down-modulate NKG2D expression. J Immunol. 2008; 180:7249-7258.

23. Taylor DD, Gercel-Taylor C, Lyons KS, Stanson J, Whiteside TL. T-cell apoptosis and suppression of T-cell receptor/CD3-zeta by Fas ligand-containing membrane vesicles shed from ovarian tumors. Clinical cancer research : an official journal of the American Association for Cancer Research. 2003; 9:5113-5119.

24. Wieckowski EU, Visus C, Szajnik M, Szczepanski MJ, Storkus WJ, Whiteside TL. Tumor-derived microvesicles promote regulatory $\mathrm{T}$ cell expansion and induce apoptosis in tumor-reactive activated CD8+ T lymphocytes. J Immunol. 2009; 183:3720-3730.

25. Whiteside TL. Immune modulation of T-cell and NK (natural killer) cell activities by TEXs (tumour-derived exosomes). Biochemical Society transactions. 2013; 41:245-251.

26. Huber V, Fais S, Iero M, Lugini L, Canese P, Squarcina $P$, Zaccheddu A, Colone M, Arancia G, Gentile M, Seregni E, Valenti R, Ballabio G, et al. Human colorectal cancer cells induce T-cell death through release of proapoptotic microvesicles: role in immune escape. Gastroenterology. 2005; 128:1796-1804.
27. Andreola G, Rivoltini L, Castelli C, Huber V, Perego P, Deho P, Squarcina P, Accornero P, Lozupone F, Lugini L, Stringaro A, Molinari A, Arancia G, et al. Induction of lymphocyte apoptosis by tumor cell secretion of FasLbearing microvesicles. The Journal of experimental medicine. 2002; 195:1303-1316.

28. Liu ZM, Wang YB, Yuan XH. Exosomes from murinederived GL26 cells promote glioblastoma tumor growth by reducing number and function of CD8+T cells. Asian Pacific journal of cancer prevention : APJCP. 2013; 14:309-314.

29. Abusamra AJ, Zhong Z, Zheng X, Li M, Ichim TE, Chin JL, Min WP. Tumor exosomes expressing Fas ligand mediate CD8+ T-cell apoptosis. Blood cells, molecules \& diseases. 2005; 35:169-173.

30. Hao S, Ye Z, Li F, Meng Q, Qureshi M, Yang J, Xiang J. Epigenetic transfer of metastatic activity by uptake of highly metastatic B16 melanoma cell-released exosomes. Experimental oncology. 2006; 28:126-131.

31. Park JE, Tan HS, Datta A, Lai RC, Zhang H, Meng W, Lim SK, Sze SK. Hypoxic tumor cell modulates its microenvironment to enhance angiogenic and metastatic potential by secretion of proteins and exosomes. Molecular \& cellular proteomics : MCP. 2010; 9:1085-1099.

32. Ohshima K, Inoue K, Fujiwara A, Hatakeyama K, Kanto K, Watanabe Y, Muramatsu K, Fukuda Y, Ogura S, Yamaguchi K, Mochizuki T. Let-7 microRNA family is selectively secreted into the extracellular environment via exosomes in a metastatic gastric cancer cell line. PloS one. 2010; 5:e13247.

33. Peinado H, Aleckovic M, Lavotshkin S, Matei I, CostaSilva B, Moreno-Bueno G, Hergueta-Redondo M, Williams C, Garcia-Santos G, Ghajar C, Nitadori-Hoshino A, Hoffman C, Badal K, et al. Melanoma exosomes educate bone marrow progenitor cells toward a pro-metastatic phenotype through MET. Nature medicine. 2012; 18:883-891.

34. Al-Nedawi K, Meehan B, Micallef J, Lhotak V, May L, Guha A, Rak J. Intercellular transfer of the oncogenic receptor EGFRvIII by microvesicles derived from tumour cells. Nature cell biology. 2008; 10:619-624.

35. Skog J, Wurdinger T, van Rijn S, Meijer DH, Gainche L, Sena-Esteves M, Curry WT Jr, Carter BS, Krichevsky AM, Breakefield XO. Glioblastoma microvesicles transport RNA and proteins that promote tumour growth and provide diagnostic biomarkers. Nature cell biology. 2008; 10:1470-1476.

36. Akers JC, Ramakrishnan V, Kim R, Phillips S, Kaimal V, Mao Y, Hua W, Yang I, Fu CC, Nolan J, Nakano I, Yang Y, Beaulieu M, et al. miRNA contents of cerebrospinal fluid extracellular vesicles in glioblastoma patients. Journal of neuro-oncology. 2015; 123:205-216.

37. Muller L, Muller-Haegele S, Mitsuhashi M, Gooding W, Okada H, Whiteside TL. Exosomes isolated from plasma of glioma patients enrolled in a vaccination trial reflect antitumor immune activity and might predict survival. Oncoimmunology. 2015; 4:e1008347. 
38. Berrondo C, Flax J, Kucherov V, Siebert A, Osinski T, Rosenberg A, Fucile C, Richheimer S, Beckham CJ. Expression of the Long Non-Coding RNA HOTAIR Correlates with Disease Progression in Bladder Cancer and Is Contained in Bladder Cancer Patient Urinary Exosomes. PloS one. 2016; 11:e0147236.

39. Koga K, Matsumoto K, Akiyoshi T, Kubo M, Yamanaka N, Tasaki A, Nakashima H, Nakamura M, Kuroki S, Tanaka M, Katano M. Purification, characterization and biological significance of tumor-derived exosomes. Anticancer research. 2005; 25:3703-3707.

40. Taylor DD, Gercel-Taylor C. MicroRNA signatures of tumor-derived exosomes as diagnostic biomarkers of ovarian cancer. Gynecologic oncology. 2008; 110:13-21.

41. Munagala R, Aqil F, Gupta RC. Exosomal miRNAs as biomarkers of recurrent lung cancer. Tumour biology : the journal of the International Society for Oncodevelopmental Biology and Medicine. 2016; 37:10703-10714.

42. Tokuhisa M, Ichikawa Y, Kosaka N, Ochiya T, Yashiro M, Hirakawa K, Kosaka T, Makino H, Akiyama H, Kunisaki C, Endo I. Exosomal miRNAs from Peritoneum Lavage Fluid as Potential Prognostic Biomarkers of Peritoneal Metastasis in Gastric Cancer. PloS one. 2015; 10:e0130472.

43. Shi R, Wang PY, Li XY, Chen JX, Li Y, Zhang XZ, Zhang CG, Jiang T, Li WB, Ding W, Cheng SJ. Exosomal levels of miRNA-21 from cerebrospinal fluids associated with poor prognosis and tumor recurrence of glioma patients. Oncotarget. 2015; 6:26971-81. https://doi.org/10.18632/ oncotarget.4699.

44. Sohn W, Kim J, Kang SH, Yang SR, Cho JY, Cho HC, Shim SG, Paik YH. Serum exosomal microRNAs as novel biomarkers for hepatocellular carcinoma. Exp Mol Med. 2015; 47:e184.

45. Li Y, Wang Z, Wang Y, Zhao Z, Zhang J, Lu J, Xu J, Li $X$. Identification and characterization of IncRNA mediated transcriptional dysregulation dictates lncRNA roles in glioblastoma. Oncotarget. 2016; 7:45027-41. https://doi. org/10.18632/oncotarget.7801.

46. Mohankumar S, Patel T. Extracellular vesicle long noncoding RNA as potential biomarkers of liver cancer. Brief Funct Genomics. 2016; 15:249-256.

47. Li Q, Shao Y, Zhang X, Zheng T, Miao M, Qin L, Wang B, Ye G, Xiao B, Guo J. Plasma long noncoding RNA protected by exosomes as a potential stable biomarker for gastric cancer. Tumour Biol. 2015; 36:2007-2012.

48. Wang J, Zhou Y, Lu J, Sun Y, Xiao H, Liu M, Tian L. Combined detection of serum exosomal miR-21 and HOTAIR as diagnostic and prognostic biomarkers for laryngeal squamous cell carcinoma. Med Oncol. 2014; $31: 148$.

49. Dong L, Lin W, Qi P, Xu MD, Wu X, Ni S, Huang D, Weng WW, Tan C, Sheng W, Zhou X, Du X. Circulating Long RNAs in Serum Extracellular Vesicles: Their Characterization and Potential Application as Biomarkers for Diagnosis of
Colorectal Cancer. Cancer Epidemiol Biomarkers Prev. 2016; 25:1158-66.

50. Thery C, Boussac M, Veron P, Ricciardi-Castagnoli P, Raposo G, Garin J, Amigorena S. Proteomic analysis of dendritic cell-derived exosomes: a secreted subcellular compartment distinct from apoptotic vesicles. J Immunol. 2001; 166:7309-7318.

51. Thery C, Regnault A, Garin J, Wolfers J, Zitvogel L, Ricciardi-Castagnoli P, Raposo G, Amigorena S. Molecular characterization of dendritic cell-derived exosomes. Selective accumulation of the heat shock protein hsc73. J Cell Biol. 1999; 147:599-610.

52. Thery C, Ostrowski M, Segura E. Membrane vesicles as conveyors of immune responses. Nat Rev Immunol. 2009; 9:581-593

53. Utsugi-Kobukai S, Fujimaki H, Hotta C, Nakazawa M, Minami M. MHC class I-mediated exogenous antigen presentation by exosomes secreted from immature and mature bone marrow derived dendritic cells. Immunol Lett. $2003 ; 89: 125-131$.

54. Andre F, Chaput N, Schartz NE, Flament C, Aubert N, Bernard J, Lemonnier F, Raposo G, Escudier B, Hsu DH, Tursz T, Amigorena S, Angevin E, et al. Exosomes as potent cell-free peptide-based vaccine. I. Dendritic cell-derived exosomes transfer functional MHC class I/peptide complexes to dendritic cells. J Immunol. 2004; 172:2126-2136.

55. Segura E, Nicco C, Lombard B, Veron P, Raposo G, Batteux F, Amigorena S, Thery C. ICAM-1 on exosomes from mature dendritic cells is critical for efficient naive T-cell priming. Blood. 2005; 106:216-223.

56. Simhadri VR, Reiners KS, Hansen HP, Topolar D, Simhadri VL, Nohroudi K, Kufer TA, Engert A, Pogge von Strandmann E. Dendritic cells release HLA-B-associated transcript-3 positive exosomes to regulate natural killer function. PLoS One. 2008; 3:e3377.

57. Munich S, Sobo-Vujanovic A, Buchser WJ, Beer-Stolz D, Vujanovic NL. Dendritic cell exosomes directly kill tumor cells and activate natural killer cells via TNF superfamily ligands. OncoImmunology. 2012; 1:1074-1083.

58. Viaud S, Terme M, Flament C, Taieb J, Andre F, Novault S, Escudier B, Robert C, Caillat-Zucman S, Tursz T, Zitvogel L, Chaput N. Dendritic cell-derived exosomes promote natural killer cell activation and proliferation: a role for NKG2D ligands and IL-15Ralpha. PLoS One. 2009; 4:e4942.

59. Beauvillain C, Ruiz S, Guiton R, Bout D, Dimier-Poisson I. A vaccine based on exosomes secreted by a dendritic cell line confers protection against $\mathrm{T}$. gondii infection in syngeneic and allogeneic mice. Microbes Infect. 2007; 9:1614-1622.

60. Hegmans JP, Hemmes A, Aerts JG, Hoogsteden HC, Lambrecht $\mathrm{BN}$. Immunotherapy of murine malignant mesothelioma using tumor lysate-pulsed dendritic cells. Am J Respir Crit Care Med. 2005; 171:1168-1177. 
61. Hao S, Ye Z, Yang J, Bai O, Xiang J. Intradermal vaccination of dendritic cell-derived exosomes is superior to a subcutaneous one in the induction of antitumor immunity. Cancer Biother Radiopharm. 2006; 21:146-154.

62. Guo F, Chang CK, Fan HH, Nie XX, Ren YN, Liu YY, Zhao LH. Anti-tumour effects of exosomes in combination with cyclophosphamide and polyinosinic-polycytidylic acid. J Int Med Res. 2008; 36:1342-1353.

63. Escudier B, Dorval T, Chaput N, Andre F, Caby MP, Novault S, Flament C, Leboulaire C, Borg C, Amigorena S, Boccaccio C, Bonnerot C, Dhellin O, et al. Vaccination of metastatic melanoma patients with autologous dendritic cell (DC) derived-exosomes: results of thefirst phase I clinical trial. J Transl Med. 2005; 3:10.

64. Morse MA, Garst J, Osada T, Khan S, Hobeika A, Clay TM, Valente N, Shreeniwas R, Sutton MA, Delcayre A, Hsu DH, Le Pecq JB, Lyerly HK. A phase I study of dexosome immunotherapy in patients with advanced non-small cell lung cancer. J Transl Med. 2005; 3:9.

65. Andre F, Schartz NE, Movassagh M, Flament C, Pautier P, Morice P, Pomel C, Lhomme C, Escudier B, Le Chevalier T, Tursz T, Amigorena S, Raposo G, et al. Malignant effusions and immunogenic tumour-derived exosomes. Lancet. 2002; 360:295-305.

66. Yao Y, Chen L, Wei W, Deng X, Ma L, Hao S. Tumor cellderived exosome-targeted dendritic cells stimulate stronger CD8+ CTL responses and antitumor immunities. Biochem Biophys Res Commun. 2013; 436:60-65.

67. Hao S, Bai O, Li F, Yuan J, Laferte S, Xiang J. Mature dendritic cells pulsed with exosomes stimulate efficient cytotoxic T-lymphocyte responses and antitumour immunity. Immunology. 2007; 120:90-102.
68. Palmer DH, Midgley RS, Mirza N, Torr EE, Ahmed F, Steele JC, Steven NM, Kerr DJ, Young LS, Adams DH. A phase II study of adoptive immunotherapy using dendritic cells pulsed with tumor lysate in patients with hepatocellular carcinoma. Hepatology. 2009; 49:124-132.

69. Gu X, Erb U, Buchler MW, Zoller M. Improved vaccine efficacy of tumor exosome compared to tumor lysate loaded dendritic cells in mice. International journal of cancer. 2015; 136:E74-84.

70. Hunn MK, Farrand KJ, Broadley KW, Weinkove R, Ferguson P, Miller RJ, Field CS, Petersen T, McConnell MJ, Hermans IF. Vaccination with irradiated tumor cells pulsed with an adjuvant that stimulates NKT cells is an effective treatment for glioma. Clin Cancer Res. 2012; 18:6446-6459.

71. Hamid O, Robert C, Daud A, Hodi FS, Hwu WJ, Kefford R, Wolchok JD, Hersey P, Joseph RW, Weber JS, Dronca R, Gangadhar TC, Patnaik A, et al. Safety and tumor responses with lambrolizumab (anti-PD-1) in melanoma. N Engl J Med. 2013; 369:134-144.

72. Tumeh PC, Harview CL, Yearley JH, Shintaku IP, Taylor EJ, Robert L, Chmielowski B, Spasic M, Henry G, Ciobanu V, West AN, Carmona M, Kivork C, et al. PD-1 blockade induces responses by inhibiting adaptive immune resistance. Nature. 2014; 515:568-571.

73. Munson P, Shukla A. Exosomes: Potential in Cancer Diagnosis and Therapy. Medicines (Basel). 2015; 2:310-327. 